\title{
Exploration in Papua: Discussion
}

Author(s): Major Darwin, Newton Moore, C. G. Rawling, A. F. R. Wollaston and Arthur Jewell

Source: The Geographical Journal, Vol. 39, No. 4 (Apr., 1912), pp. 331-334

Published by: geographicalj

Stable URL: http://www.jstor.org/stable/1778661

Accessed: 24-06-2016 11:39 UTC

Your use of the JSTOR archive indicates your acceptance of the Terms \& Conditions of Use, available at

http://about.jstor.org/terms

JSTOR is a not-for-profit service that helps scholars, researchers, and students discover, use, and build upon a wide range of content in a trusted digital archive. We use information technology and tools to increase productivity and facilitate new forms of scholarship. For more information about JSTOR, please contact support@jstor.org.

The Royal Geographical Society (with the Institute of British Geographers), Wiley are collaborating with JSTOR to digitize, preserve and extend access to The Geographical Journal 
The "leaf" or "stick" insects were fairly plentiful, and in some instances their resemblance to the plant life in their immediate environment was wonderfully accurate. One insect resembled a stick covered with green moss; the green colouring appeared so exactly like moss, that a member of our party refused to believe it was not actually moss antil he had examined it with a magnifying glass.

On the map accompanying this report the course of that portion of the Kikor river lying to the west of the 144th meridian of east longitude is only approximate, as, while descending this river, most of our instruments were lost, and the compass-bearings and estimated speed could not be checked by observations for latitude. In addition to which the great difficulties that beset us on our return journey did not permit of the careful mapping previously undertaken.

The most important results of the exploration were-

(1) We went practically right across the centre of the unexplored portion of the territory of Papua, travelling approximately 524 miles through totally unexplored country ( 374 miles on foot and 150 by river).

(2) We ascertained that instead of the Western Divisior of Papua being low-lying recent alluvial country, as previously supposed, it is (except along the coast and in the vicinity of its navigable rivers) an upraised plateau having an area of approximately 12,000 square miles, the lowest valley being over 2000 feet above sea-level.

(3) The upper waters and watersheds of the great rivers emptying into the Papuan gulf are now roughly defined, thus completing our knowledge of the river systems of the territory.

(4) We have now data for estimating the population of the whole territory with some accuracy, the hinterland of the Western Division being formerly an unknown quantity.

(5) We found coal deposits in two places along the watershed of the Kikor river, the coal country along its upper waters being very extensive.

(6) We found sago growing inland as far as we penetrated and at an elevation up to 3500 feet.

(7) We established friendly relations with the natives everywhere, and were successful in avoiding all fighting.

Major Darwin, Vice-president (before the lecture) : I am very sorry that our President, Lord Curzon, although he was able to attend our Council meeting this afternoon, is still suffering from such a bad cold that he is advised not to go out to-night.

Our lecturer to-night deals with the unknown parts of New Guinea. That territory was handed over by the Home Government to the Commonwealth of Australia some seven years ago, and is now administered by the Dominion Government. The administration is in the hands of a Lieut.-Governor and an Administrator, and in making the appointment of Administrator the Dominion Government naturally selected one of their own citizens-one who was born in Australia, educated in Australia, and who had served in the Senate 
of the Australian Commonwealth - Mr. Staniforth Smith, our lecturer of tonight. I will not anticipate his remarks about his plucky journey. He was away rather longer than he expected, and in his absence certain sinister rumours were circulated in Australia, which I am very glad to say turned out to be entirely untrue, for had they been true he would not have been here to-night.

Sir Newton Moore (after the lecture): Although I have no personal know. ledge of Papua, I have a very intimate knowledge of the lecturer, as, although a native of Victoria, he spent a good deal of his time in Western Australia, and was mayor of the great city of Kalgoorlie for a considerable time, and afterwards was one of the first senators to enter the Commonwealth Parliament as a representative of Western Australia. He proved to be an excellent legislator, and I think you will understand from to-night that he is a practical administrator, that he is prepared to endeavour to acquire a knowledge of the territory he is in charge of, and is prepared to risk his life in order to gain that knowledge. I sympathize with him in his work, as that little instrument that you saw with the surveyor is one I have carried for many thousands of miles in Western Australia, and have had an opportunity of judging from personal experience some of the hardships they would have to undergo in the western districts and undeveloped portions of the territory, and it speaks highly for Mr. Staniforth Smith that he and his party were able to carry out this great work in the systematic manner they have done. They have located many important points, and been able to fill in many blank spaces in the map of New Guinea, and I can only say it has been a great treat to me to-night to have had an opportunity of listening to his lecture, and am proud, as a fellow-Australian, of the work he and his party have dene.

Captain C. G. RAws,ING: I will not detain you many minutes; but must congratulate Mr. Staniforth Smith upon having delivered one of the most interesting lectures I have heard at the Society. My remarks will take the form of a comparison between the obstacles to travel in Papua and in the Mimika district, in which we have of late been working: 600 miles divide the two territories. In the Mimika district it is quite impossible to maintain a rate of progress of 3 miles a day, not only because of the density of the forest, but of the fact that the hills are uninhabited. This means that, instead of relying upon fresh supplies being obtained for the carriers from the natives, every ounce of food has to be carried, necessitating depôts and a line of communication being kept open. The fact of there being no inhabitants in the mountains alone is sufficient to prove that the vegetation is far denser in the west than in Papua. Mr. Staniforth Smith tells us that he found sago growing at a height of 3500 feet; in the Mimika district not one sago tree was found 100 feet above sea-level. With respect to the minerals, it is interesting to note that the coal discovered was hard and good, while that come across by Dr. Lorentz and by our expedition proved soft and useless. A point of interest to anthropologists is brought forward by the fact that the new tribes Mr. Staniforth Smith was amongst make fire in identically the same way as that used by the Tapiro pygmies. Now, these tribes are separated by 600 miles of almost impassable country, with a great snow-clad range between, a belt of uninhabited land, and many hostile tribes (none of whom make fire in this way). Why the same plan is used, how they learnt it, whether they do communicate with one another by some means, I am unable to say; no doubt some anthropologists will be able to solve the question. I must again congratulate Mr. Smith on having brought himself and so many men through one of the most difficult and venturesome 
journeys of discovery. His chief fault was apparently that of travelling too fast, that of our late expedition of moving too slowly.

Mr. A. F. R. Wollaston: I have listened with great interest to this most remarkable lecture by Mr. Staniforth Smith. I will, if I may, draw your attention to the extreme modesty of some of the lecturer's descriptions, which can hardly be appreciated by people who have not been in the country. In those brief remarks of his, when he says "we crossed a mountain range," "went up a valley and crossed another mountain range," you may read between the lines pages-I might almost say volumes-of trials and tribulations that he had to go through. In suggesting that the inhabitants of the Sambregi villages at 6000 feet were living at the highest altitude of any Papuans so far visited, Mr. Staniforth Smith has, I think, forgotten the Papuans whom Dr. Lorentz found living up to a height of 10,000 feet on the slopes of Mount Wilhelmina. The note about tobacco is particularly interesting. The name Suku shows a marked difference of language from that of the Papuans of south Dutch New Guinea, who are unable to pronounce the letter $s$. Then, again, Mr. Smith suggests that the name is probably derived from the coastal name $K u k u$, and that on that account the tobacco is probably an introduced plant. But may it not be conversely, that the coastal is derived from the inland name? There are many considerations pointing to the possibility of tobacco being an indigenous plant in New Guinea; in a great number of places the best tobacco is grown on the mountains in the interior, whence it is traded to the people near the coasts ; and on the upper waters of the Fly and Kaiserin Augusta rivers tobacco was known to be in use long before it was known to the natives along the lower parts of those rivers. The use of the split stick and rattan for making fire by the people of this region is interesting, as affording another link in the chain of places where this method is employed; the other places are the Owen Stanley range in British New Guinea, the hills at the head of the Noord river and the Mimika river (Tapiro pygmy people) in Dütch New Guinea, Sarawak, and at some places in the Malay peninsula. It may not be out of place here to suggest that it is not yet too late to alter the name Papua, which has been applied by the Australian Government to the territory formerly known as British New Grinea. The word Papua (pronounced Papoóa) signifies "woolly," and is in use among the Malays of the archipelago, who apply it to the woolly-headed natives of New Guinea, and in course of time the island itself came to be called Papua. The true Papuans, as recognized by anthropologists, are more characteristic of Dutch than of British New Guinea, where they are in a small minority, so that, apart from the absurdity of its meaning, it seems a pity to name the territory Papua.

Mr. Arthur Jewell: I have had the pleasure of being very closely associated with New Guinea for the past nine years, and as far back as 1904 I spent eleven weeks as one of a Government expedition in the deltas of the rivers about which Mr. Smith has been speaking to-night. Mr. Smith has enumerated many of the advantages and good results accruing from an expedition of this kind, but there is one, if I may be permitted to say so, which he has apparently overlooked, and that is in connection with the industrial development of the country. It is after such work as Mr. Smith's that industrial development follows, for we are put in possession of knowledge relating to the agricultural, mining, and labour resources of a hitherto unknown country. The peaceful pacification of the natives is perhaps the most important feature of such expeditions, and I am sure you will agree that all who are interested in any way in this great and wonderful country, whether scientifically, industrially, or 
otherwise, must feel themselves under a debt of gratitude to Mr. Smith for work he has done.

Major Darwin: I know nothing about New Guinea myself, but, as you know, I have been to many lectures in this building. There are three qualities every explorer must have: he must have personal courage, he must have forethought, and he must have the aptitude of making friends with the natives. I think our lecturer has been conspicuous in all these three qualities. Only one other thing is necessary, and that is a bit of good luck. Whether to say he had good luck or bad luck, I do not know; he had extremely bad luck in certain respects, but he had the good luck that he was not drowned, and on that I think we all congratulate him. He evidently ran very great risks. I am sure I may, in the name of everybody present, congratulate him on his success, and thank him for his most interesting lecture.

\title{
JOURNEY THROUGH A PORTION OF SOUTH-EASTERN TIBET AND THE MISHMI HILLS.*
}

\author{
By Captain F. M. BAILEY.
}

THE following account of a journey through a small unsurveyed portion of south-eastern Tibet and the Mishmi hills may be of interest in view of the military and political measures recently taken in consequence of the murder of Mr. Williamson and Dr. Gregorson by the Abors.

I travelled out by the Siberian railway, and after being detained for a week in quarantine, on account of the plague which was raging in Manchuria, reached Peking on March 8, 1911. Having spent a week in the capital and obtained a passport, I took the train to Hankau, where it was necessary to wait for some days before an up-river steamer left for Ichang. From Ichang I passed up through the Yangtse gorges, about which so much has been written, in company with Mr. Hill of the Chinese Customs, who shared a house-boat with me for this part of the journey; unfortunately, we were wrecked in one of the rapids, and obliged to pass the night in the open. On reaching Wan-Hsien, I spent two days with Mr. and Mrs. Ortolani, of the Imperial Post Office, while making preparations for my 400-mile journey to Chengtu. At Chengtu I enjoyed the hospitality of Mr. Wilkinson, H.B.M.'s Consul-General, for a few days before continuing my journey. At Ya-chou Fu I called on one of the large firms engaged in the Tibetan tea trade, and saw coarse tea-bricks being made. At Ta-chien-lu, where the first Tibetans were met with, I sent back a useless Chinese servant who had accompanied me from Peking, and took in his place a Tibetan, who remained with me until I was about to enter the Mishmi country.

From Ta-chien-lu I made an excursion in search of Takin (Budorcas taxicolor) to a place some 15 miles to the south, crossing a pass called Boi La (13,240 feet), which on May 14 was covered with snow about a foot deep. From here some very distant snow mountains were visible to the

* Map, p. 420 . 